\title{
Traditional Indian Medicines Used for the Management of Diabetes Mellitus
}

\author{
Syed Ibrahim Rizvi ${ }^{1}$ and Neetu Mishra ${ }^{2}$ \\ ${ }^{1}$ Department of Biochemistry, University of Allahabad, Allahabad 211002, India \\ ${ }^{2}$ Centre of Food Technology, University of Allahabad, Allahabad 211002, India \\ Correspondence should be addressed to Syed Ibrahim Rizvi; sirizvi@gmail.com
}

Received 7 April 2013; Accepted 16 May 2013

Academic Editor: Pinar Atukeren

Copyright ( 2013 S. I. Rizvi and N. Mishra. This is an open access article distributed under the Creative Commons Attribution License, which permits unrestricted use, distribution, and reproduction in any medium, provided the original work is properly cited.

\begin{abstract}
Plants have always been a source of drugs for humans since time immemorial. The Indian traditional system of medicine is replete with the use of plants for the management of diabetic conditions. According to the World Health Organization, up to $90 \%$ of population in developing countries use plants and its products as traditional medicine for primary health care. There are about 800 plants which have been reported to show antidiabetic potential. The present review is aimed at providing in-depth information about the antidiabetic potential and bioactive compounds present in Ficus religiosa, Pterocarpus marsupium, Gymnema sylvestre, Allium sativum, Eugenia jambolana, Momordica charantia, and Trigonella foenum-graecum. The review provides a starting point for future studies aimed at isolation, purification, and characterization of bioactive antidiabetic compounds present in these plants.
\end{abstract}

\section{Introduction}

Diabetes mellitus is a growing problem worldwide entailing enormous financial burden and medical care policy issues [1]. According to International Diabetes Federation (IDF), the number of individuals with diabetes in 2011 crossed 366 million, with an estimated 4.6 million deaths each year [2]. The Indian subcontinent has emerged as the capital of this diabetes epidemic. The reported prevalence of diabetes in adults between the ages of 20 and 79 is as follows: India 8.31\%, Bangladesh 9.85\%, Nepal 3.03\%, Sri Lanka 7.77\%, and Pakistan 6.72\% [3].

Indians show a significantly higher age-related prevalence of diabetes when compared with several other populations [4]. For a given BMI, Asian Indians display a higher insulin level which is an indicator of peripheral insulin resistance. The insulin resistance in Indians is thought to be due to their higher body fat percentage $[5,6]$. Excess body fat, typical abdominal deposition pattern, low muscle mass, and racial predisposition may explain the prevalence of hyperinsulinemia and increased development of type 2 diabetes in Asian Indians.
Diabetes is characterized by metabolic dysregulation primarily of carbohydrate metabolism, manifested by hyperglycemia resulting from defects in insulin secretion, impaired insulin action, or both [7]. Uncontrolled diabetes leads to a plethora of complications affecting the vascular system, eyes, nerves, and kidneys leading to peripheral vascular disease, nephropathy, neuropathy, retinopathy, morbidity, and/or mortality.

According to the World Health Organization (WHO), up to $90 \%$ of the population in developing countries uses plants and its products as traditional medicine for primary health care [8]. The WHO has listed 21,000 plants, which are used for medicinal purposes around the world. Among these, 2500 species are in India [9]. There are about 800 plants which have been reported to show antidiabetic potential [10]. A wide collection of plant-derived active principles representing numerous bioactive compounds have established their role for possible use in the treatment of diabetes [10].

The most common and effective antidiabetic medicinal plants of Indian origin are Babul (Acacia arabica), bael (Aegle marmelose), church steeples (Agrimonia eupatoria), onion (Allium cepa), garlic (Allium sativum), ghrita kumara 
(Aloe vera), neem (Azadirachta indica), ash gourd (Benincasa hispida), Beetroot (Beta vulgaris), fever nut (Caesalpinia bonducella), bitter apple (Citrullus colocynthis), ivy gourd (Coccinia indica), eucalyptus (Eucalyptus globules), banyan tree (Ficus benghalenesis), gurmar (Gymnema sylvestre), gurhal (Hibiscus rosa-sinesis), sweet potato (Ipomoea batatas), purging Nut (Jatropha curcas), mango (Mangifera indica), karela (Momordica charantia), mulberry (Morus alba), kiwach (Mucuna pruriens), tulsi (Ocimum sanctum), bisasar (Pterocarpus marsupium), anar (Punica granatum), jamun (Syzygium cumini), giloy (Tinospora cordifolia), and methi (Trigonella foenum-graecum). All these plants are a rich source of phytochemicals.

The present review presents the antidiabetic efficacy of some important plants used in traditional system of medicine in India for the management of type 2 diabetes mellitus.

\section{Indian Medicinal Plants with Antidiabetic Potential}

2.1. Ficus religiosa. Ficus religiosa, commonly known as peepal in India, belongs to family Moraceae. Ficus religiosa has been reported to be used in the traditional system of Ayurveda for the treatment of diabetes [11]. F. religiosa has been shown to possess a wide spectrum of in vitro and in vivo pharmacological activities: antidiabetic, hypolipidemic, anticonvulsant, anti-inflammatory, analgesic, antimicrobial, antiviral, antioxidant, antitumor, antiulcer, antianxiety, anthelmintic, antiasthmatic, immunomodulatory, estrogenic, endothelin receptor antagonist, apoptosis inducer, cognitive enhancer, and antihypertensive [12].

Decoction prepared from the bark is used in treatment of diabetes [13]. The plant is believed to contain several bioactive principles including tannins, saponins, polyphenolic compounds, flavonoids, and sterols. Sitosterol-d-glucoside present in the bark of Ficus religiosa is believed to elicit hypoglycemic activity in rabbits [14]. The bioactive components present in Ficus are leucocyandin 3-O-beta-d-galactosyl cellobioside, leucopelargonidin-3-O-alpha-L rhamnoside $[15$, 16]. The phytoconstituents present in Ficus can impart a significant antidiabetic effect. It has been reported to contain phytosterols, flavonoids, tannins, and furanocoumarin derivatives, namely, bergapten and bergaptol [17].

The leaves of Ficus religiosa have also been studied for antihyperglycemic activity [18]. Oral incorporation of aqueous extract of Ficus religiosa for 21 days caused a significant lowering in blood glucose levels, and an elevated level of insulin has been observed. The skeletal muscle is an important site for insulin-stimulated glucose uptake. Decrease in muscle and hepatic glycogen in diabetes was observed to be corrected by peepal extract $[19,20]$.

Secondary complications of diabetes that is hypercholesteremia and hypertriglyceridemia were found to decrease through significantly reduced serum triglycerides and total cholesterol levels in STZ-diabetic rats [21]. Administration of aqueous extract of bark at the dose of $500 \mathrm{mg} / \mathrm{kg}$ has been reported to ameliorate blood glucose level, hepatic enzymes, and lipid parameters in streptozotocin-induced diabetic rats [22].

Oxidative stress is one of the major etiologies in the pathogenesis and complications of type 2 diabetes. F. religiosa has been reported to modulate the enzymes of antioxidant defence system to combat oxidative stress. Restoration of glutathione and inhibition of malondialdehyde content has shown the antioxidative property of Ficus religiosa [23].

2.2. Eugenia jambolana. Eugenia jambolana (black plum or jamun) belongs to the family Myrtaceae. The most commonly used plant parts are seeds, leaves, fruits, and bark. Eugenia jambolana is an evergreen tropical tree of 8 to $15 \mathrm{~m}$ height, with smooth, glossy turpentine-smelling leaves. The bark is scaly gray, and the trunk is forked. There are fragrant white flowers in branched clusters at stem tips and purplish-black oval edible berries. The berries contain only one seed. The taste is generally acidic to fairly sweet but astringent. This tree is known to have grown in Indian subcontinent and in other regions of South Asia such as Nepal, Burma, Sri Lanka, Indonesia, Pakistan, and Bangladesh from ancient time.

Jamun has been reported to be used in numerous complementary and alternative medicine systems of India and, before the discovery of insulin, was a frontline antidiabetic medication even in Europe. The brew prepared by jamun seeds in boiling water has been used in the various traditional systems of medicine in India [24].

Eugenia jambolana is one of the widely used medicinal plants in the treatment of diabetes and several other diseases. The plant is rich in compounds containing anthocyanins, glucoside, ellagic acid, isoquercetin, kaempferol, myricetin, and hydrolysable tannins (1-0-galloyl castalagin and casuarinin). The seeds also contain alkaloid jambosine and glycoside jamboline, which slows down the diastatic conversion of starch into sugar [25].

The whole plant of Eugenia jambolana is reported to show antioxidative defence due to numerous phytochemical constituents present in it. The bark of jamun is rich in several bioactive compounds including quercetin, betulinic acid, Bsitosterol, eugenin, ellagic and gallic acid [26], bergenin [27], tannins [28], and flavonoids. Fruits contain glucose, fructose, raffinose [29], malic acid [30], and anthocyanins [31]; leaves are rich in acylated flavonol glycosides [32], quercetin, myricetin, and tannins [33] all of which have hypoglycemic ability.

The blood glucose-lowering effect of Eugenia jambolana may be due to increased secretion of insulin from the pancreas or by inhibition of insulin degradation [34]. Eugenia jambolana is also reported to have lipid-lowering effect evidenced by reduction of blood cholesterol, triglycerides, and free fatty acids [35]. This effect has been reported to be due to the presence of flavonoids, saponins, and glycosides in the extract which is reported to decrease the activity of enzyme 3-HMG Co-A reductase in liver [36]. Eugenia jambolana seed extract is reported to reduce blood pressure probably due to the ellagic acid present in it [33].

Addition of ethanolic extract of seeds and seed powder of Eugenia jambolana in alloxan-induced diabetic rats showed 
significant reduction in blood sugar level and enhancement in the histopathology of pancreatic islets [37]. Decrease in glycosuria and blood urea levels has also been reported. Similar kind of results has also been reported in numerous studies done on dogs and rabbits [38,39].

Eugenia jambolana fruit juice is diuretic and has been reported to provide a soothing effect on human digestive system [40]. The gastroprotective effect has also been reported in jamun seeds. Elevation of antioxidant status and mucosal defensive properties might be the possible mechanisms behind gastroprotective properties present in jamun. Presence of flavanoids in the seeds provides the gastric ulcer protective activity to jamun [40]. Jamun shows antiviral activity against goat pox and the highly pathogenic avian influenza (H5N1) virus $[41,42]$.

The efficacy of Eugenia jambolana has also been tested in preclinical and clinical studies $[43,44]$ for hypolipidemic [45], anti-inflammatory, [46], neuropsychopharmacological [47], antiulcer, [48], antibacterial [49], anti-HIV [50], antidiarrhoeal [49], and antihypertensive activities [47].

2.3. Momordica charantia. Momordica charantia (bitter gourd or karela) belongs to the family Cucurbitaceae. Fruit as a whole and fruit's seeds are the parts most frequently used for therapeutic benefits. Momordica charantia is a popular fruit used for the treatment of diabetes, cardiovascular diseases, and related conditions amongst the indigenous population of Asia, South America, and East Africa. It is often used as a vegetable in diet. Bitter gourd contains bioactive substances with antidiabetic potential such as vicine, charantin, and triterpenoids along with some antioxidants [51]. Several preclinical studies have documented the antidiabetic and hypoglycaemic effects of Momordica charantia through various hypothesised mechanisms [52].

Several studies have demonstrated antibacterial, antiviral, anticancer, and antidiabetic activities, in Momordica charantia $[53,54]$; however, the antidiabetic activity has been widely reviewed. In several animal studies, bitter gourd has been reported to ameliorate the metabolic syndrome, where diabetes is one of the risk factors [55-57]. In a study conducted on Taiwanese adults, a significant reduction in waist circumference, improvement in diabetes, and symptoms of metabolic syndrome has been observed [58].

The hypoglycemic and lipid-lowering properties of bitter melon have been observed [59]. Studies have shown that Momordica charantia can repair damaged $\beta$-cells thereby stimulating insulin levels [60] and also improve sensitivity/signalling of insulin [57]. Bitter gourd is also reported to inhibit absorption of glucose by inhibiting glucosidase and suppressing the activity of disaccharidases in the intestine [61].

Ethanolic extract of Momordica charantia is reported to show antihyperglycemic effect in normal and streptozotocin diabetic rats which might be due to inhibition of glucose-6-phosphatase and also stimulation of the activity of hepatic glucose-6-phosphate dehydrogenase [62]. Studies have reported that triterpenoids may be the hypoglycemic components present in karela which could be responsible for activation of AMP-activated protein kinase [63]. The blood glucose-lowering activity of karela has been reported in several animal models [64].

Bitter melon is also effective in loosening adiposity. It is reported to decrease the weight of epididymal and retroperitoneal white adipose tissues [54]. Bitter melon is found effective in augmenting skeletal muscle strength, an effect which could be due to higher mRNA expression for the glucose transporter 4 [55]. Extracts/fractions of Antidesma madagascariense and Momordica charantia were found to significantly inhibit the activity of $\alpha$-glucosidase, a key carbohydrate hydrolyzing enzyme. However, glycogenloaded mice showed significant depressive effect on increasing the level of postprandial blood glucose after ingestion of Momordica charantia [65]. Presence of saponins to some extent might justify the inhibitory activities on $\alpha$-amylase and $\alpha$-glucosidase. Saponins are also supposed to stimulate insulin secretion [66].

2.4. Ocimum sanctum. Ocimum sanctum L. (holy basil or tulsi) belongs to the family Lamiaceae. Every part of the plant is used as a therapeutic agent against several diseases. Ocimum (holy basil) is reported to grow worldwide. Nutritional and chemical composition of holy basil makes it a plant with immense potential. Eugenol, the active constituent present in $O$. sanctum L., has been found to be responsible for its therapeutic potential [67]. Major bioactive constituents present in the leaves and stems of holy basil include flavonoids, saponins, tannins, triterpenoids, rosmarinic acid, apigenin, isothymusin, isothymonin, cirsimaritin, orientin, and vicenin. Tulsi leaves oil contains eugenol, ursolic acid, carvacrol, linalool, limatrol, and caryophyllene along with eugenol. Seeds oil is known to have fatty acids and sitosterol while seed mucilage contains some sugars. Anthocyanins are present in green leaves. Furthermore, tulsi is also rich in vitamins, minerals, chlorophyll, and many other phytonutrients.

Antidiabetic properties of tulsi were appreciated in Ayurveda [68]. A significant reduction in blood glucose, glycosylated hemoglobin, and urea along with a simultaneous increase in glycogen, hemoglobin, and protein in streptozotocin-induced diabetic rats has been observed when rats were supplemented with ethanolic extract of $O$. sanctum [69]. Leaf extract of $O$. sanctum $\mathrm{L}$ has been reported to stimulate the physiological pathways of insulin secretion [70]. $O$. sanctum L. showed serum glucose-lowering effect when the extract was given to normal rats for 30 days [71]. $O$. sanctum $\mathrm{L}$. is reported to reduce the serum level of cortisol and glucose in male mice showing its antiperoxidative effect [72].

Studies have reported that oral administration of alcoholic extract of leaves of $O$. sanctum L. significantly reduced blood sugar level in normal, glucose-fed hyperglycemic, and streptozotocin-induced diabetic rats. Improvement in the action of exogenous insulin in normal rats has also been recorded [73]. Mixed extract of $P$. marsupium and O. sanctum has been recorded to not only rectify dyslipidemia but also restore the endogenous antioxidant levels in alloxan-induced diabetic rats [74]. 
Chloroform extracts of aerial parts of tulsi have been able to ameliorate the derangements in lipid metabolism caused due to diabetes mellitus in alloxan-induced diabetic rats. The extract significantly decreased elevated level of serum glucose and also reversed the cholesterol, triglyceride, and LDL values [75].

The hydroalcoholic extract of $O$. sanctum L. given to stress-induced male Wister rats is reported to significantly prevent the chronic resistant stress induced rise in plasma cAMP level, myocardial superoxide dismutase, and catalase activities [76]. Ursolic acid isolated from O. sanctum L. has been reported to protect heart cells from Adriamycininduced lipid peroxidation [77]. O. sanctum L is also used to control blood cholesterol. A marked decrease in serum cholesterol, triacylglycerol, and LDL + VLDL cholesterol as compared to untreated cholesterol-fed group was observed in cholesterol-fed rabbits when supplemented with $O$. sanctum L. seed oil for four weeks [78]. A similar kind of study performed on normal albino rabbits showed lowered levels of serum total cholesterol, triglyceride, phospholipids, and LDL-cholesterol and a significant boost in the HDLcholesterol and total fecal sterol contents with incorporation of fresh leaves of tulsi [79].

Along with antidiabetic and cardioprotective effects, $O$. sanctum L. has also been suggested to acquire antifungal [80], antimicrobial [81], analgesic [82], anthelmintic [83], antistress [9], antifertility [84], anti-inflammatory [85], antioxidant $[78,86]$, gastroprotective [87], immunomodulatory [88], antithyroidic [89], anticancer [90], and radioprotective effects $[91,92]$. Tulsi is reported to provide a protection for central nervous system [93] and against sexually transmitted diseases [94].

2.5. Pterocarpus marsupium. Pterocarpus marsupium (indian kino tree, bijasar) belongs to the family Fabaceae. Plant parts used most commonly are heart wood, leaves, flowers, bark, and gum. Pterocarpus marsupium grows very well in India, Nepal, and Sri Lanka. As per Ayurveda, it is one of the most versatile medicinal plants with a wide spectrum of biological activities. Every part of the tree has been acknowledged for its therapeutic potential. This tree grows up to 30 metres in height. Compositional studies on bijasar have shown this plant to be a good source of polyphenols. P. marsupium contains terpenoids and phenolic compounds: $\beta$-sitosterol, lupenol, aurone glycosides, epicatechins, and iso-flavonoids $[95,96]$.

P. marsupium is known for its antidiabetic activity [97]. Besides eliciting a strong antidiabetic property, Pterocarpus marsupium is reported to be effective against several diseases. It is reported to be antiobesity, antihyperlipidemic [98], antiinflammatory, anthelmentic $[99,100]$, antioxidative, antitumorigenic and antiulcerative [71, 101].

Pterocarpus marsupium is reported to have not only hypoglycemic property but also $\beta$-cell protective and regenerative properties [102], effects which have been attributed to the flavonoid content in the plant. Complete restoration of normal insulin secretion and regeneration of beta cells have been reported in various experimental models of diabetes
[103, 104]. A methanolic extract of Pterocarpus marsupium when supplemented for 7 and 14 days to STZ-diabetic rats showed normalization of streptozotocin-distressed serum glucose by correcting glycosylated hemoglobin (HbAlc), serum protein, insulin, alkaline and acid phosphatase, and albumin levels [105].

The blood sugar-lowering activity has been endorsed to be due to the presence of tannates in the extract of the plant. Antihyperlipidemic activity is contributed probably to the marsupin, pterosupin, and liquiritigenin present in the plant [106]. (-) Epicatechin has been shown to have insulinogenic property by enhancing insulin release and conversion of proinsulin to insulin. (-) Epicatechin has also been shown to possess insulin-like activity $[107,108]$. Epicatechin has also been shown to strengthen the insulin signalling by activating key proteins of that pathway and regulating glucose production through AKT and AMPK modulation in HepG2 cells [109].

2.6. Trigonella foenum-graecum. Trigonella foenum-graecum (fenugreek, methi) belongs to the family Fabaceae. Seeds and leaves are the most frequently used parts of the plant. Trigonella foenum-graecum L. (fenugreek) is cultivated throughout India and in some other parts of the world as a semiarid crop [80]. It is used both as a vegetable and as a spice in India. Fenugreek is well known for its pungent aromatic properties, and it is a flavoring agent in food [110]. Studies on different experimental models have proved that fenugreek has strong antidiabetic properties [111, 112]. Human studies have also confirmed the glucose and lipid-lowering ability of fenugreek [113].

Several studies have demonstrated that fenugreek seed extract, mucilage of seeds, and leaves can decrease blood glucose and cholesterol levels in humans and experimental diabetic animals $[114,115]$. The therapeutic potential of fenugreek is primarily due to the presence of saponins [116], 4-hydroxyisoleucine [117], and trigonelline, an alkaloid [118] and a high-fiber content [119].

The antihyperglycemic effect has been correlated with decline in somatostatin and high plasma glucagon levels [120]. Fenugreek seed powder has been shown to normalize the activity of creatinine kinase in liver, skeletal muscles, and heart of diabetic rats [121]. The antihyperglycemic effect of fenugreek has been hypothesized to be due to the amino acid 4-hydroxyisoleucine which acts by the enhancement of insulin sensitivity and glucose uptake in peripheral tissues [122]. The steroids present in methi have been reported to reduce blood glucose level when supplemented to diabetic rats [123]. A considerable increment of the area of insulinimmunoreactive $\beta$ cells has been observed [124].

A study on intestinal and renal disaccharidases activity in STZ-induced diabetic rats proved the beneficial effects of fenugreek seed mucilage by enhancing the reduction in maltase activity during diabetes [125]. The optimistic influence of fenugreek supplementation on intestinal and renal disaccharidases has been reported [126]. A marked reduction in renal toxicity has been observed when fenugreek oil is incorporated in the diet of alloxanized rats [125]. 
2.7. Gymnema sylvestre. Gymnema sylvestre (gurmar) belongs to the family Asclepiadaceae. It is a herb native to the tropical forests of India and Sri Lanka. G. sylvestre is a large climber, with roots at nodes. It is a potent antidiabetic plant used in ayurvedic preparations. Several studies have proved its antidiabetic potential in animal models [125]; when combined with acarbose it is reported to reduce intestinal transport of maltose in rats [127]. Absorption of free oleic acid in rats has also been reduced [128].

Aqueous extract of G. sylvestre has been reported to cause reversible increases in intracellular calcium and insulin secretion in mouse and human $\beta$ cells with type 2 diabetes [129]. Regeneration of the cells in the pancreas might raise the insulin levels [130]. G. sylvestre can also help prevent adrenal hormones from stimulating the liver to produce glucose in mice, thereby reducing blood sugar levels [131]. A group of triterpene saponins, known as gymnemic acids and gymnemasaponins are found to be present in G. sylvestre which are responsible for the reported pharmacological properties.

Oral administration of Gymnema is reported to be effective against chronic inflammation [132], obesity [133, 134], and pancreatic $\beta$ cell dysfunction [135]. G. sylvestre suspension shows tremendous diabetic potential against alloxaninduced diabetic albino male rats [136]. The hypoglycemic effect of ethanolic extract of G. sylvestre is reported to be due to enhanced effect of insulin which comes into play by increasing either the pancreatic secretion of insulin from $\beta$ cells or its release from the bound form $[130,137$, 138]. A significant correlation between the good glycemic control and phospholipid levels has been observed [139]. Oral administration of $G$. sylvestre to rats has been reported to result in increased utilization of glucose and/or by decreasing mobilization of fat [136]. A significant reduction in body weight, plasma proteins, and total hemoglobin levels has also been observed [136].

2.8. Allium sativum. Allium sativum (garlic) commonly called lahsun belongs to the family Amaryllidaceae. Leaves and bulb are the parts frequently used. As per Ayurveda it is a miraculous plant used against a variety of problems including insect bites, intestinal worms, headache, and tumors [140]. Garlic is also used in folk medicine for the management of cardiac diseases, cancer, parasitic, fungal diseases, and diabetes $[141,142]$. The principle bioactive components present in garlic are allicin, allixin, ajoene, and other organosulphur compounds.

Biological and therapeutic functions of garlic are basically due to the organosulphur compounds they possess [143]. These chemical components are thought to exhibit numerous biological effects including lowering of cholesterol and glucose, cancer prevention, and antimicrobial properties [144]. Studies have proved that the consumption of garlic significantly decreased fasting blood sugar levels [145]. Diallyl trisulfide has been proved to improve glycemic control in STZ-induced diabetic rats. [146] Incorporation of garlic juice resulted in better utilization of glucose in glucose tolerance tests performed in rabbits, while allicin at a dose of $250 \mathrm{mg} / \mathrm{kg}$ was $60 \%$ as effective as tolbutamide in alloxan-induced diabetic rabbits [147].

Garlic may act as an antidiabetic agent by increasing either the pancreatic secretion of insulin from the $\beta$ cells or the release of bound insulin [148]. Allicin is supposed to enhance serum insulin by combining with cysteine and sparing it from SH group reactions [147]. The beneficial effects of $\mathrm{N}$-acetylcysteine, an organosulfur from allium plants, on serum lipids and glucose are related to its antioxidant property. N-Acetylcysteine is reported to reduce the oxidative stress by improving the endogenous antioxidant defences [149].

Allicin, a sulfur-containing compound, is responsible for the pungent flavour and significant hypoglycemic activity in garlic. This effect is supposed to be due to enhanced hepatic metabolism, release of insulin, and/or insulin-sparing effect $[150,151]$. S-allyl cystein sulfoxide the precursor of allicin is reported to control lipid peroxidation and hyperglycemia in rats [152].

Cardiovascular complications of diabetes are reported to be prevented by the consumption of garlic [153]. Saponins are reported to reduce serum cholesterol levels [154]. Garlic juice has been found to exert antioxidant and antihyperglycemic effects in alloxan-induced diabetic rats [155].

Phytochemicals present in garlic also show antioxidative property evidenced by scavenging of reactive oxygen species [156] and increasing cellular antioxidant enzymes: superoxide dismutase, catalase, and glutathione peroxidase [157]. Garlic alone and with ginger and turmeric when tested against oxidative stress in streptozotocin (STZ)-nicotinamide diabetic rats showed $80-97 \%$ increment in the signs of hyperglycaemia and dyslipidaemia, $26-37 \%$ increase in the production of insulin and enrichment in the antioxidant defence system along with a $60-97 \%$ decrease in lipid peroxidation [158]. Administration of raw garlic homogenate was found to normalise both hepatic TBARS and GSH levels and also improve insulin sensitivity and oxidative stress in fructose-fed rats [159]. Numerous studies report that aged garlic extract inhibit the generation of glycation-derived free radicals and AGEs in vitro. S-Allyl cysteine, one of the bioactive ingredients of aged garlic, is a known antioxidant that possesses the capacity to inhibit AGEs synthesis [160].

\section{Conclusion}

As per Ayurveda, there exists a huge collection of plants with antidiabetic potential. Only few of them have been scientifically proven and a lot more have yet to be explored and proved. Ficus religiosa, Gymnema sylvestre, Allium sativum, Trigonella foenum graecum, Pterocarpus marsupium, Ocimum sanctum, Momordica charantia, Eugenia jambolana, and Ficus religiosa have shown varying degrees of hypoglycemic activity. These plants have also been reported to contribute in control of complications of diabetes. Future studies may target isolation, purification, and characterization of bioactive compounds present in these plants. The outcome of such studies may provide a starting point for development of potential antidiabetic drugs. This review may be helpful in the management of diabetes. 


\section{Conflict of Interests}

The authors declare that they have no conflict of interests.

\section{References}

[1] L. K. Keter and P. C. Mutiso, "Ethnobotanical studies of medicinal plants used by Traditional Health Practitioners in the management of diabetes in Lower Eastern Province, Kenya," Journal of Ethnopharmacology, vol. 139, no. 1, pp. 74-80, 2012.

[2] H. Dong, N. Wang, L. Zhao, and F. Lu, "Berberine in the treatment of type 2 diabetes mellitus: a systemic review and meta-analysis," Evidence-Based Complementary and Alternative Medicine, vol. 2012, Article ID 591654, 12 pages, 2012.

[3] N. Unwin, D. Whiting, L. Guariguata, G. Ghyoot, and D. Gan, IDF. Diabetes Atlas, International Diabetes Federation, Brussels, Belgium, 5th edition, 2011.

[4] M. K. Ali, K. M. V. Narayan, and N. Tandon, "Diabetes \& coronary heart disease: current perspectives," Indian Journal of Medical Research, vol. 132, no. 11, pp. 584-597, 2010.

[5] M. A. Banerji, N. Faridi, R. Atluri, R. L. Chaiken, and H. E. Lebovitz, "Body composition, visceral fat, leptin, and insulin resistance in Asian Indian men," Journal of Clinical Endocrinology and Metabolism, vol. 84, no. 1, pp. 137-144, 1999.

[6] V. Dudeja, A. Misra, R. M. Pandey, G. Devina, G. Kumar, and N. K. Vikram, "BMI does not accurately predict overweight in Asian Indians in northern India," British Journal of Nutrition, vol. 86, no. 1, pp. 105-112, 2001.

[7] Y. V. Sashikanth, P. Aravindkumar, and C. Swarupa, "Two way relation of diabetes mellitus and periodontitis-a review," Annals and Essences of Dentistry, vol. 4, no. 1, 2012.

[8] World Health Organization, "Traditional medicine-growing needs and potential," WHO Policy Perspective on Medicines, vol. 2, pp. 1-6, 2002.

[9] M. Modak, P. Dixit, J. Londhe, S. Ghaskadbi, and T. P. A. Devasagayam, "Indian herbs and herbal drugs used for the treatment of diabetes," Journal of Clinical Biochemistry and Nutrition, vol. 40, no. 3, pp. 163-173, 2007.

[10] R. Patil, R. Patil, B. Ahirwar, and D. Ahirwar, "Current status of Indian medicinal plants with antidiabetic potential: a review," Asian Pacific Journal of Tropical Biomedicine, vol. 1, no. 2, pp. S291-S298, 2011.

[11] M. Simmonds and M. Howes, "Plants used in the treatment of diabetes," in Traditional Medicines for Modern Time-Antidiabetic Plants, A. Soumyanath, Ed., vol. 6th, pp. 19-82, CRC Press/Taylor and Francis Group, 2006.

[12] D. Singh, B. Singh, and R. K. Goel, "Traditional uses, phytochemistry and pharmacology of Ficus religiosa: a review," Journal of Ethnopharmacology, vol. 134, no. 3, pp. 565-583, 2011.

[13] Agnivesha, Prameha Chikitsa, Charak Samhita, Choukhambha Sanskrita Sansthan, Varanasi, 2001.

[14] S. Ambike and M. Rao, "Studies on a phytosterolin fromthe bark of Ficus religiosa," The Indian Journal of Pharmacy, vol. 29, pp. 91-94, 1967.

[15] M. Bnouham, A. Ziyyat, H. Mekhfi, A. Tahri, and A. Legssyer, "Medicinal plants with potential antidiabetic activity-a review of ten years of herbal medicine research (1990-2000)," International Journal of Diabetes and Metabolism, vol. 14, no. 1, pp. 1-25, 2006.

[16] S. Ayodhya, S. Kusum, and S. Anjali, "Hypoglycemic activity of different extracts of various herbal plants Singh," International
Journal of Ayurveda and Research in Pharmacy, vol. 1, no. 1, pp. 212-224, 2010.

[17] K. D. Swami and N. P. S. Bisht, "Constituents of Ficus religiosa and Ficus infectoria and their Biological Activity," Journal of the Indian Chemical Society, vol. 73, no. 11, p. 631, 1996.

[18] T. A. Deshmukh, B. V. Yadav, S. L. Badole, S. L. Bodhankar, and S. R. Dhaneshwar, "Antihyperglycaemic activity of petroleum ether extract of Ficus racemosa fruits in alloxan induced diabetic mice," Pharmacologyonline, vol. 2, pp. 504-515, 2007.

[19] C. Bouché, S. Serdy, C. R. Kahn, and A. B. Goldfine, "The cellular fate of glucose and its relevance in type 2 diabetes," Endocrine Reviews, vol. 25, no. 5, pp. 807-830, 2004.

[20] J. K. Grover, V. Vats, and S. Yadav, "Effect of feeding aqueous extract of Pterocarpus marsupium on glycogen content of tissues and the key enzymes of carbohydrate metabolism," Molecular and Cellular Biochemistry, vol. 241, no. 1-2, pp. 53-59, 2002.

[21] R. Ananthan, M. Latha, K. M. Ramkumar, L. Pari, C. Baskar, and V. Narmatha Bai, "Effect of Gymnema montanum leaves on serum and tissue lipids in alloxan diabetic rats," Experimental Diabesity Research, vol. 4, no. 3, pp. 183-189, 2003.

[22] M. Gayathri and K. Kannabiran, "Antidiabetic and ameliorative potential of Ficus bengalensis bark extract in streptozotocin induced diabetic rats," Indian Journal of Clinical Biochemistry, vol. 23, no. 4, pp. 394-400, 2008.

[23] H. Kirana, S. S. Agrawal, and B. P. Srinivasan, "Aqueous extract of Ficus religiosa Linn. reduces oxidative stress in experimentally induced type 2 diabetic rats," Indian Journal of Experimental Biology, vol. 47, no. 10, pp. 822-826, 2009.

[24] M. S. Baliga, S. Fernandes, K. R. Thilakchand, P. D’souza, and S. Rao, "Scientific validation of the antidiabetic effects of Syzygium jambolanum DC (Black Plum), a traditional medicinal plant of India," Journal Alternative and Complemenaryt Medicine, vol. 19, no. 3, pp. 191-197, 2013.

[25] M. Ayyanar and P. Subash-Babu, "Syzygium cumini (L.) Skeels: a review of its phytochemical constituents and traditional uses," Asian Pacific Journal of Tropical Biomedicine, vol. 2, no. 3, pp. 240-246, 2012.

[26] A. K. N. Chaudhuri, S. Pal, A. Gomes, and S. Bhattacharya, "Anti-inflammatory and related actions of Syzygium cuminii seed extract," Phytotherapy Research, vol. 4, no. 1, pp. 5-10, 1990.

[27] I. S. Bhatia and K. L. Bajaj, "Chemical constituents of the seeds and bark of Syzygium cumini," Planta Medica, vol. 28, no. 4, pp. 346-352, 1975.

[28] H. C. Srivastava, "Paper chromatography of fruit juices," Journal of Scientific and Industrial Research, vol. 12, pp. 363-365, 1953.

[29] Y. S. Lewis, C. T. Dwarakanath, and D. S. Johar, "Acids and sugars in Eugenia jambolana," Journal of Scientific and Industrial Research, vol. 15, pp. 280-281, 1956.

[30] K. Ravi, S. Rajasekaran, and S. Subramanian, "Antihyperlipidemic effect of Eugenia jambolanaseed kernel on streptozotocin-induced diabetes in rats," Food and Chemical Toxicology, vol. 43, no. 9, pp. 1433-1439, 2005.

[31] J. K. Grover, V. Vats, and S. S. Rathi, "Anti-hyperglycemic effect of Eugenia jambolana and Tinospora cordifolia in experimental diabetes and their effects on key metabolic enzymes involved in carbohydrate metabolism," Journal of Ethnopharmacology, vol. 73, no. 3, pp. 461-470, 2000.

[32] K. K. Bhargava, R. Dayal, and T. R. Seshadri, "Chemical components of Eugenia jambolanastem bark," Current Science, vol. 43, pp. 645-646, 1974. 
[33] J. Morton, Fruits of Warm Climates, Julia Morton Winterville, Miami, Fla, USA, 1987.

[34] M. J. Aybar, A. N. Sánchez Riera, A. Grau, and S. S. Sánchez, "Hypoglycemic effect of the water extract of Smallantus sonchifolius (yacon) leaves in normal and diabetic rats," Journal of Ethnopharmacology, vol. 74, no. 2, pp. 125-132, 2001.

[35] H. Sagrawat, A. S. Mann, and M. D. Kharya, "Pharmacological potential of Eugenia jambolana: a review," Pharmacognosy Magazine, vol. 2, no. 6, pp. 96-105, 2006.

[36] K. Ravi, B. Ramachandran, and S. Subramanian, "Effect of Eugenia jambolana seed kernel on antioxidant defense system in streptozotocin-induced diabetes in rats," Life Sciences, vol. 75, no. 22, pp. 2717-2731, 2004.

[37] N. Singh and M. Gupta, "Effects of ethanolic extract of Syzygium cumini (Linn) seed powder on pancreatic islets of alloxan diabetic rats," Indian Journal of Experimental Biology, vol. 45, no. 10, pp. 861-867, 2007.

[38] D. S. Shrotri, "Investigation of hypoglycemic properties of Vinca rosea, Cassia auriculata and Eugenia jambolana," Indian Journal of Medical Research, vol. 51, p. 464, 1963.

[39] P. Kedar and C. H. Chakrabarti, "Effects of jambolan seed treatment on blood sugar, lipids and urea in streptozotocin induced diabetes in rabbits," Indian Journal of Physiology and Pharmacology, vol. 27, no. 2, pp. 135-140, 1983.

[40] A. Chaturvedi, M. Mohan Kumar, G. Bhawani, H. Chaturvedi, M. Kumar, and R. K. Goel, "Effect of ethanolic extract of Eugenia jambolana seeds on gastric ulceration and secretion in rats," Indian Journal of Physiology and Pharmacology, vol. 51, no. 2, pp. 131-140, 2007.

[41] R. Sood, D. Swarup, S. Bhatia et al., "Antiviral activity of crude extracts of Eugenia jambolana Lam. against highlypathogenic avian influenza (H5N1) virus," Indian Journal of Experimental Biology, vol. 50, no. 3, pp. 179-186, 2012.

[42] V. Bhanuprakash, M. Hosamani, V. Balamurugan et al., "In vitro antiviral activity of plant extracts on goatpox virus replication," Indian Journal of Experimental Biology, vol. 46, no. 2, pp. 120 127, 2008.

[43] S. B. Sharma, A. Nasir, K. M. Prabhu, P. S. Murthy, and G. Dev, "Hypoglycaemic and hypolipidemic effect of ethanolic extract of seeds of Eugenia jambolana in alloxan-induced diabetic rabbits," Journal of Ethnopharmacology, vol. 85, no. 2-3, pp. 201206, 2003.

[44] L. Kopanski and G. Schnelle, "Isolation of bergenin from barks of Syzygium cumini," Planta Medica, vol. 54, p. 572, 1988.

[45] D. Chakrabarty, P. K. Mahapatra, and A. K. N. Chaudhuri, "A Neuro-psycopharmacological study of Syzygium cumini," Planta Medica, vol. 2, pp. 139-1143, 1985.

[46] A. Chaturvedi, G. Bhawani, P. K. Agarwal, S. Goel, A. Singh, and R. K. Goel, "Antidiabetic and antiulcer effects of extract of Eugenia jambolana seed in mild diabetic rats: study on gastric mucosal offensive acid-pepsin secretion," Indian Journal of Physiology and Pharmacology, vol. 53, no. 2, pp. 137-146, 2009.

[47] M. S. A. Bhuiyan, M. Younus Mia, and M. A. Rashid, "Antibacterial principles of the seeds of Eugenia jambolana," Bangladesh Journal of Botany, vol. 25, no. 2, pp. 239-241, 1996.

[48] I. T. Kusumoto, T. Nakabayashi, H. Kida et al., "Screening of various plant extracts used in ayurvedic medicine for inhibitory effects on human immunodeficiency virus type 1 (HIV-1) protease," Phytotherapy Research, vol. 9, no. 3, pp. 180-184, 1995.

[49] G. Indira and R. Mohan, Jamun Fruits, National Institute of Nutrition. ICMR, Hyderabad, India, 1993.
[50] R. T. Cirqueira and M. J. Q. F. Alves, "Hypotensive and diuretic effects of pitanga (Eugenia uniflora L.) and jambos (Eugenia jambolana Lam.) aqueous extracts in normotensive anesthetized rats," Revista Brasileira de Plantas Medicinais, vol. 7, no. 2, pp. 86-91, 2005.

[51] M. B. Krawinkel and G. B. Keding, "Bitter gourd (Momordica charantia): a dietary approach to hyperglycemia," Nutrition Reviews, vol. 64, no. 7, pp. 331-337, 2006.

[52] L. Leung, R. Birtwhistle, J. Kotecha, S. Hannah, and S. Cuthbertson, "Anti-diabetic and hypoglycaemic effects of Momordica charantia (bitter melon): a mini review," British Journal of Nutrition, vol. 102, no. 12, pp. 1703-1708, 2009.

[53] J. K. Grover and S. P. Yadav, "Pharmacological actions and potential uses of Momordica charantia: a review," Journal of Ethnopharmacology, vol. 93, no. 1, pp. 123-132, 2004.

[54] E. Basch, S. Gabardi, and C. Ulbricht, "Bitter melon (Momordica charantia): a review of efficacy and safety," American Journal of Health-System Pharmacy, vol. 60, no. 4, pp. 356-359, 2003.

[55] V. Gadang, W. Gilbert, N. Hettiararchchy, R. Horax, L. Katwa, and L. Devareddy, "Dietary bitter melon seed increases peroxisome proliferator-activated receptor- $\gamma$ gene expression in adipose tissue, down-regulates the nuclear factor- $\kappa \mathrm{B}$ expression, and alleviates the symptoms associated with metabolic syndrome," Journal of Medicinal Food, vol. 14, no. 1-2, pp. 8693, 2011.

[56] C. C. Shih, C. H. Lin, W. L. Lin, and J. B. Wu, "Momordica charantia extract on insulin resistance and the skeletal muscle GLUT4 protein in fructose-fed rats," Journal of Ethnopharmacology, vol. 123, no. 1, pp. 82-90, 2009.

[57] Z. Q. Wang, X. H. Zhang, Y. Yu et al., "Bioactives from bitter melon enhance insulin signaling and modulate acyl carnitine content in skeletal muscle in high-fat diet-fed mice," Journal of Nutritional Biochemistry, vol. 22, no. 11, pp. 1064-1073, 2011.

[58] C. Tsai, E. C. Chen, H. Tsay, and C. Huang, "Wild bitter gourd improves metabolic syndrome: a preliminary dietary supplementation trial," Nutrition Journal, vol. 11, no. 1, article 4, 2012.

[59] I. Inayat-ur-Rahman, S. A. Malik, M. Bashir, R. Khan, and M. Iqbal, "Serum sialic acid changes in non-insulin-dependant diabetes mellitus (NIDDM) patients following bitter melon (Momordica charantia) and rosiglitazone (Avandia) treatment," Phytomedicine, vol. 16, no. 5, pp. 401-405, 2009.

[60] A. Saxena and N. K. Vikram, "Role of selected Indian plants in management of type 2 diabetes: a review," Journal of Alternative and Complementary Medicine, vol. 10, no. 2, pp. 369-378, 2004.

[61] P. Chaturvedi, "Antidiabetic potentials of Momordica charantia: multiple mechanisms behind the effects," Journal of Medicinal Food, vol. 15, no. 2, pp. 101-107, 2012.

[62] B. A. Shibib, L. A. Khan, and R. Rahman, "Hypoglycaemic activity of Coccinia indica and Momordica charantia in diabetic rats: depression of the hepatic gluconeogenic enzymes glucose6-phosphatase and fructose-1,6-bisphosphatase and elevation of both liver and red-cell shunt enzyme glucose-6-phosphate dehydrogenase," Biochemical Journal, vol. 292, no. 1, pp. 267270, 1993.

[63] H. L. Cheng, H. K. Huang, C. I. Chang, C. P. Tsai, and C. H. Chou, "A cell-based screening identifies compounds from the stem of Momordica charantia that overcome insulin resistance and activate AMP-activated protein kinase," Journal of Agricultural and Food Chemistry, vol. 56, no. 16, pp. 68356843, 2008. 
[64] Z. A. Malik, M. Singh, and P. L. Sharma, "Neuroprotective effect of Momordica charantia in global cerebral ischemia and reperfusion induced neuronal damage in diabetic mice," Journal of Ethnopharmacology, vol. 133, no. 2, pp. 729-734, 2011.

[65] M. Fawzi Mahomoodally, A. Hussein Subratty, A. GuribFakim, M. Iqbal Choudhary, and S. Nahar Khan, "Traditional medicinal herbs and food plants have the potential to inhibit key carbohydrate hydrolyzing enzymes in vitro and reduce postprandial blood glucose peaks in vivo," Scientific World Journal, vol. 2012, pp. 284-285, 2012.

[66] A. C. Keller, J. Ma, A. Kavalier, K. He, A. B. Brillantes, and E. J. Kennelly, "Saponins from the traditional medicinal plant Momordica charantia stimulate insulin secretion in vitro," Phytomedicine, vol. 19, no. 1, pp. 32-37, 2011.

[67] P. Pattanayak, P. Behera, D. Das, and S. Panda, "Ocimum sanctum Linn. A reservoir plant for therapeutic applications: an overview," Pharmacognosy Reviews, vol. 4, no. 7, pp. 95-105, 2010.

[68] V. Khan, A. K. Najmi, M. Akhtar, M. Aqil, M. Mujeeb, and K. K. Pillai, "A pharmacological appraisal of medicinal plants with antidiabetic potential," Journal of Pharmacy and Bioallied Sciences, vol. 4, no. 1, pp. 27-42, 2012.

[69] R. T. Narendhirakannan, S. Subramanian, and M. Kandaswamy, "Biochemical evaluation of antidiabetogenic properties of some commonly used Indian plants on streptozotocin-induced diabetes in experimental rats," Clinical and Experimental Pharmacology and Physiology, vol. 33, no. 12, pp. 1150-1157, 2006.

[70] J. M. A. Hannan, L. Marenah, L. Ali, B. Rokeya, P. R. Flatt, and Y. H. A. Abdel-Wahab, "Ocimum sanctum leaf extracts stimulate insulin secretion from perfused pancreas, isolated islets and clonal pancreatic $\beta$-cells," Journal of Endocrinology, vol. 189, no. 1, pp. 127-136, 2006.

[71] R. Nair, T. Kalariya, and S. Chanda, "Antibacterial activity of some selected Indian medicinal flora," Turkish Journal of Biology, vol. 29, pp. 41-47, 2005.

[72] S. Gholap and A. Kar, "Hypoglycaemic effects of some plant extracts are possibly mediated through inhibition in corticosteroid concentration," Pharmazie, vol. 59, no. 11, pp. 876-878, 2004.

[73] R. R. Chattopadhyay, "Hypoglycemic effect of Ocimum sanctum leaf extract in normal and streptozotocin diabetic rats," Indian Journal of Experimental Biology, vol. 31, no. 11, pp. 891-893, 1993.

[74] P. K. Singh, D. Baxi, S. Banerjee, and A. V. Ramachandran, "Therapy with methanolic extract of Pterocarpus marsupium Roxb and Ocimum sanctum Linn reverses dyslipidemia and oxidative stress in alloxan induced type I diabetic rat model," Experimental and Toxicologic Pathology, vol. 64, no. 5, pp. 441448, 2012.

[75] R. N. Patil, R. Y. Patil, B. Ahirwar, and D. Ahirwar, "Evaluation of antidiabetic and related actions of some Indian medicinal plants in diabetic rats," Asian Pacific Journal of Tropical Medicine, vol. 4, no. 1, pp. 20-23, 2011.

[76] S. Sood, D. Narang, M. K. Thomas, Y. K. Gupta, and S. K. Maulik, "Effect of Ocimum sanctum Linn. on cardiac changes in rats subjected to chronic restraint stress," Journal of Ethnopharmacology, vol. 108, no. 3, pp. 423-427, 2006.

[77] S. Balanehru and B. Nagarajan, "Intervention of Adriamycin induced free radical damage," Biochemistry International, vol. 28, no. 4, pp. 735-744, 1992.

[78] M. T. Salles Trevisan, M. G. Vasconcelos Silva, B. Pfundstein, B. Spiegelhalder, and R. W. Owen, "Characterization of the volatile pattern and antioxidant capacity of essential oils from different species of the genus Ocimum," Journal of Agricultural and Food Chemistry, vol. 54, no. 12, pp. 4378-4382, 2006.

[79] A. Sarkar, S. C. Lavania, D. N. Pandey, and M. C. Pant, "Changes in the blood lipid profile after administration of Ocimum sanctum (Tulsi) leaves in the normal albino rabbits," Indian Journal of Physiology and Pharmacology, vol. 38, no. 4, pp. 311312, 1994.

[80] B. Kavishankar, N. Lakshmidevi, S. Mahadeva, H. S. Murthy, S. R. Prakash, and Niranjana, "Diabetes and medicinal plantsa review," International Journal of Pharmacy and Biomedical Science, vol. 2, no. 3, pp. 65-80, 2011.

[81] S. Singh, M. Malhotra, and D. K. Majumdar, "Antibacterial activity of Ocimum sanctum L. fixed oil," Indian Journal of Experimental Biology, vol. 43, no. 9, pp. 835-837, 2005.

[82] N. Khanna and J. Bhatia, "Antinociceptive action of Ocimum sanctum (Tulsi) in mice: possible mechanisms involved," Journal of Ethnopharmacology, vol. 88, no. 2-3, pp. 293-296, 2003.

[83] M. K. Asha, D. Prashanth, B. Murali, R. Padmaja, and A. Amit, "Anthelmintic activity of essential oil of Ocimum sanctum and eugenol," Fitoterapia, vol. 72, no. 6, pp. 669-670, 2001.

[84] M. Ahmed, R. N. Ahamed, R. H. Aladakatti, and M. G. Ghosesawar, "Reversible anti-fertility effect of benzene extract of Ocimum sanctum leaves on sperm parameters and fructose content in rats," Journal of Basic and Clinical Physiology and Pharmacology, vol. 13, no. 1, pp. 51-59, 2002.

[85] M. A. Kelm, M. G. Nair, G. M. Strasburg, and D. L. DeWitt, "Antioxidant and cyclooxygenase inhibitory phenolic compounds from Ocimum sanctum Linn," Phytomedicine, vol. 7, no. 1, pp. 7-13, 2000.

[86] S. U. Yanpallewar, S. Rai, M. Kumar, and S. B. Acharya, "Evaluation of antioxidant and neuroprotective effect of Ocimum sanctum on transient cerebral ischemia and long-term cerebral hypoperfusion," Pharmacology Biochemistry and Behavior, vol. 79, no. 1, pp. 155-164, 2004.

[87] R. K. Goel, K. Sairam, M. Dorababu, T. Prabha, and C. V. Rao, "Effect of standardized extract of Ocimum sanctum Linn. on gastric mucosal offensive and defensive factors," Indian Journal of Experimental Biology, vol. 43, no. 8, pp. 715-721, 2005.

[88] R. Mukherjee, P. K. Dash, and G. C. Ram, "Immunotherapeutic potential of Ocimum sanctum (L) in bovine subclinical mastitis," Research in Veterinary Science, vol. 79, no. 1, pp. 37-43, 2005.

[89] S. Panda and A. Kar, "Ocimum sanctum leaf extract in the regulation of thyroid function in the male mouse," Pharmacological Research, vol. 38, no. 2, pp. 107-110, 1998.

[90] J. Prakash and S. K. Gupta, "Chemopreventive activity of Ocimum sanctum seed oil," Journal of Ethnopharmacology, vol. 72, no. 1-2, pp. 29-34, 2000.

[91] U. S. Bhartiya, Y. S. Raut, L. J. Joseph, and B. S. Rao, "Protective effect of Ocimum sanctum L after high-dose 131iodine exposure in mice: an in vivo study," Indian Journal of Experimental Biology, vol. 44, no. 8, pp. 647-652, 2006.

[92] M. Subramanian, G. J. Chintalwar, and S. Chattopadhyay, "Antioxidant and radioprotective properties of an Ocimum sanctum polysaccharide," Redox Report, vol. 10, no. 5, pp. 257264, 2005.

[93] H. Joshi and M. Parle, "Evaluation of nootropic potential of Ocimum sanctum Linn. in mice," Indian Journal of Experimental Biology, vol. 44, no. 2, pp. 133-136, 2006.

[94] P. Shokeen, K. Ray, M. Bala, and V. Tandon, "Preliminary studies on activity of Ocimum sanctum, Drynaria quercifolia, 
and Annona squamosa against Neisseria gonorrhoeae," Sexually Transmitted Diseases, vol. 32, no. 2, pp. 106-111, 2005.

[95] J. Mitra and T. Joshi, "Isoflavonoids from the heartwood of Pterocarpus marsupium," Phytochemistry, vol. 22, no. 10, pp. 2326-2327, 1983.

[96] N. Kumar and T. R. Seshadri, "A new triterpene from Pterocarpus santalinus bark," Phytochemistry, vol. 15, no. 9, pp. 1417-1418, 1976.

[97] B. Kameswara Rao, R. Giri, M. M. Kesavulu, and C. Apparao, "Effect of oral administration of bark extracts of Pterocarpus santalinus L. on blood glucose level in experimental animals," Journal of Ethnopharmacology, vol. 74, no. 1, pp. 69-74, 2001.

[98] H. R. Ambujakshi and S. Ganapaty, "Anti obese activity of Pterocarpus marsupium barks extract in experimentally induced obese rats," Inventi Impact: Nutraceuticals, 2011.

[99] S. Hougee, J. Faber, A. Sanders et al., "Selective COX-2 inhibition by a Pterocarpus marsupium extract characterized by pterostilbene, and its activity in healthy human volunteers," Planta Medica, vol. 71, no. 5, pp. 387-392, 2005.

[100] V. R. Salunkhe, A. V. Yadav, A. S. Shete, S. R. Kane, and A. S. Kulkarni, "Anti-inflammatory activity of hydrogels of extracts of Pterocarpus marsupium and Coccinia indica," Indian Drugs, vol. 42, no. 5, pp. 319-321, 2005.

[101] J. K. Grover, V. Vats, and S. S. Yadav, “Pterocarpus marsupium extract (Vijayasar) prevented the alteration in metabolic patterns induced in the normal rat by feeding an adequate diet containing fructose as sole carbohydrate," Diabetes, Obesity and Metabolism, vol. 7, no. 4, pp. 414-420, 2005.

[102] B. K. Chakravarthy, S. Gupta, S. S. Gambhir, and K. D. Gode, "The prophylactic action of (-)-epicatechin against alloxan induced diabetes in rats," Life Sciences, vol. 29, no. 20, pp. 20432047, 1981.

[103] M. Manickam, M. Ramanathan, M. A. Farboodniay Jahromi, J. P. N. Chansouria, and A. B. Ray, "Antihyperglycemic activity of phenolics from Pterocarpus marsupium," Journal of Natural Products, vol. 60, no. 6, pp. 609-610, 1997.

[104] B. K. Chakravarthy, S. Gupta, and K. D. Gode, "Functional beta cell regeneration in the islets of pancreas in alloxan-induced diabetic rats by (-)-epicatechin," Life Sciences, vol. 31, no. 24, pp. 2693-2697, 1982.

[105] R. Gupta and R. S. Gupta, "Effect of Pterocarpus marsupium in streptozotocin-induced hyperglycemic state in rats: comparison with glibenclamide," Diabetologia Croatica, vol. 38, no. 2, pp. 39-45, 2009.

[106] M. A. Farboodniay Jahromi, A. B. Ray, and J. P. N. Chansouria, "Antihyperlipidemic effect of flavonoids from Pterocarpus marsupium," Journal of Natural Products, vol. 56, no. 7, pp. 989-994, 1993.

[107] F. Ahmad, P. Khalid, M. M. Khan, A. K. Rastogi, and J. R. Kidwai, "Insulin like activity in (-) epicatechin," Acta Diabetologica Latina, vol. 26, no. 4, pp. 291-300, 1989.

[108] S. I. Rizvi and M. A. Zaid, "Intracellular reduced glutathione content in normal and type 2 diabetic erythrocytes: effect of insulin and (-) epicatechin," Journal of Physiology and Pharmacology, vol. 52, no. 3, pp. 483-488, 2001.

[109] I. Cordero-Herrera, M. A. Martín, L. Bravo, L. Goya, and S. Ramos, "Cocoa flavonoids improve insulin signalling and modulate glucose production via AKT and AMPK in HepG2 cells," Molecular Nutrition and Food Research, 2013.

[110] A. Pandey, P. Tripathi, R. Pandey, R. Srivatava, and S. Goswami, "Alternative therapies useful in the management of diabetes: a systematic review," Journal of Pharmacy and Bioallied Science, vol. 3, no. 4, pp. 504-512, 2011.

[111] P. Kumar, R. K. Kale, and N. Z. Baquer, "Antihyperglycemic and protective effects of Trigonella foenum graecum seed powder on biochemical alterations in alloxan diabetic rats," European Reviews in Medicine and Pharmacology Sciences, vol. 16, no. 3, pp. 18-27, 2012.

[112] K. T. Roberts, “The potential of fenugreek (Trigonella foenumgraecum) as a functional food and nutraceutical and its effects on glycemia and lipidemia," Journal of Medicinal Food, vol. 14, no. 12, pp. 1485-1489, 2011.

[113] R. D. Sharma, T. C. Raghuram, and N. S. Rao, "Effect of fenugreek seeds on blood glucose and serum lipids in Type I diabetes," European Journal of Clinical Nutrition, vol. 44, no. 4, pp. 301-306, 1990.

[114] A. Gupta, R. Gupta, and B. Lal, "Effect of Trigonella foenumgraecum (fenugreek) seeds on glycaemic control and insulin resistance in type 2 diabetes mellitus: a double blind placebo controlled study," Journal of Association of Physicians of India, vol. 49, pp. 1057-1061, 2001.

[115] V. Vats, J. K. Grover, and S. S. Rathi, "Evaluation of antihyperglycemic and hypoglycemic effect of Trigonella foenumgraecum Linn, Ocimum sanctum Linn and Pterocarpus marsupium Linn in normal and alloxanized diabetic rats," Journal of Ethnopharmacology, vol. 79, no. 1, pp. 95-100, 2002.

[116] P. R. Petit, Y. D. Sauvaire, D. M. Hillaire-Buys et al., "Steroid saponins from fenugreek seeds: extraction, purification, and pharmacological investigation on feeding behavior and plasma cholesterol," Steroids, vol. 60, no. 10, pp. 674-680, 1995.

[117] Y. Sauvaire, P. Petit, C. Broca et al., "4-hydroxyisoleucine: a novel amino acid potentiator of insulin secretion," Diabetes, vol. 47, no. 2, pp. 206-210, 1998.

[118] T. C. Raghuram, R. D. Sharma, B. Sivakumar, and B. K. Sahay, "Effect of fenugreek seeds on intravenous glucose disposition in non-insulin dependent diabetic patients," Phytotherapy Research, vol. 8, no. 2, pp. 83-86, 1994.

[119] L. Ali, A. K. Azad Khan, Z. Hassan et al., "Characterization of the hypoglycemic effects of Trigonella foenum gracecum seed," Planta Medica, vol. 61, no. 4, pp. 358-360, 1995.

[120] G. Ribes, Y. Sauvaire, C. Da Costa, and M. M. LoubatieresMariani, "Antidiabetic effects of subfractions from fenugreek seeds in diabetic dogs," Proceedings of the Society for Experimental Biology and Medicine, vol. 182, no. 2, pp. 159-166, 1986.

[121] S. Genet, R. K. Kale, and N. Z. Baquer, "Effects of vanadate, insulin and fenugreek (Trigonella foenum graecum) on creatine kinase levels in tissues of diabetic rat," Indian Journal of Experimental Biology, vol. 37, no. 2, pp. 200-202, 1999.

[122] A. B. Singh, A. K. Tamarkar, S. Shweta, T. Narender, and A. K. Srivastava, "Antihyperglycaemic effect of an unusual amino acid (4-hydroxyisoleucine) in C57BL/KsJ-db/db mice," Natural Product Research, vol. 24, no. 3, pp. 258-265, 2010.

[123] K. Hamden, B. Jaouadi, S. Carreau et al., "Potential protective effect on key steroidogenesis and metabolic enzymes and sperm abnormalities by fenugreek steroids in testis and epididymis of surviving diabetic rats," Archives of Physiology and Biochemistry, vol. 116, no. 3, pp. 146-155, 2010.

[124] K. Hamden, H. Masmoudi, S. Carreau, and A. Elfeki, "Immunomodulatory, $\beta$-cell, and neuroprotective actions of fenugreek oil from alloxan-induced diabetes," Immunopharmacology and Immunotoxicology, vol. 32, no. 3, pp. 437-445, 2010.

[125] G. Suresh Kumar, A. K. Shetty, and P. V. Salimath, "Modulatory effect of fenugreek seed mucilage and spent turmeric on 
intestinal and renal disaccharidases in streptozotocin induced diabetic rats," Plant Foods for Human Nutrition, vol. 60, no. 2, pp. 87-91, 2005.

[126] Y. Sugihara, H. Nojima, H. Matsuda, T. Murakami, M. Yoshikawa, and I. Kimura, "Antihyperglycemic effects of gymnemic acid IV, a compound derived from Gymnema sylvestre leaves in streptozotocin-diabetic mice," Journal of Asian Natural Products Research, vol. 2, no. 4, pp. 321-327, 2000.

[127] H. Luo, L. F. Wang, T. Imoto, and Y. Hiji, "Inhibitory effect and mechanism of acarbose combined with gymnemic acid on maltose absorption in rat intestine," World Journal of Gastroenterology, vol. 7, no. 1, pp. 9-15, 2001.

[128] L. F. Wang, H. Luo, M. Miyoshi, T. Imoto, Y. Hiji, and T. Sasaki, "Inhibitory effect of gymnemic acid on intestinal absorption of oleic acid in rats," Canadian Journal of Physiology and Pharmacology, vol. 76, no. 10-11, pp. 1017-1023, 1998.

[129] H. Asare-Anane, G. C. Huang, S. A. Amiel, P. M. Jones, and S. J. Persaud, "Stimulation of insulin secretion by an aqueous extract of Gymnema sylvestre: role of intracellular calcium," Endocrine Abstracts, vol. 10, DP1, 2005.

[130] S. J. Persaud, H. Al-Majed, A. Raman, and P. M. Jones, "Gymnema sylvestre stimulates insulin release in vitro by increased membrane permeability," Journal of Endocrinology, vol. 163, no. 2, pp. 207-212, 1999.

[131] S. Gholap and A. Kar, "Effects of Inula racemosa root and Gymnema sylvestre leaf extracts in the regulation of corticosteroid induced diabetes mellitus: involvement of thyroid hormones," Pharmazie, vol. 58, no. 6, pp. 413-415, 2003.

[132] M. J. Leach, "Gymnema sylvestre for diabetes mellitus: a systematic review," Journal of Alternative and Complementary Medicine, vol. 13, no. 9, pp. 977-983, 2007.

[133] H. G. Preuss, D. Bagchi, M. Bagchi, C. V. S. Rao, D. K. Dey, and S. Satyanarayana, "Effects of a natural extract of (-)-hydroxycitric acid (HCA-SX) and a combination of HCA-SX plus niacinbound chromium and Gymnema sylvestre extract on weight loss," Diabetes, Obesity and Metabolism, vol. 6, no. 3, pp. 171-180, 2004.

[134] W. T. Cefalu, J. Ye, and Z. Q. Wang, "Efficacy of dietary supplementation with botanicals on carbohydrate metabolism in humans," Endocrine, Metabolic and Immune Disorders, vol. 8, no. 2, pp. 78-81, 2008.

[135] A. Al-Romaiyan, B. Liu, H. Asare-Anane et al., "A novel Gymnema sylvestre extract stimulates insulin secretion from human islets in vivo and in vitro," Phytotherapy Research, vol. 24, no. 9, pp. 1370-1376, 2010.

[136] R. Karthic, S. Nagaraj, P. Arulmurugan, S. Seshadri, R. Rengasamy, and K. Kathiravan, "Gymnema sylvestre suspension cell extract show antidiabetic potential in Alloxan induced diabetic albino male rats," Asia Pacific Journal of Tropical Biomedicine, vol. 2, supplement, pp. S930-S933, 2012.

[137] B. Liu, H. Asare-Anane, A. Al-Romaiyan et al., "Characterisation of the insulinotropic activity of an aqueous extract of Gymnema sylvestre in mouse $\beta$-cells and human islets of Langerhans," Cellular Physiology and Biochemistry, vol. 23, no. 1-3, pp. 125-132, 2009.

[138] A. R. Saltiel and C. R. Kahn, "Insulin signalling and the regulation of glucose and lipid metabolism," Nature, vol. 414, no. 6865, pp. 799-806, 2001.

[139] S. K. Jain, "Glutathione and glucose-6-phosphate dehydrogenase deficiency can increase protein glycosylation," Free Radical Biology and Medicine, vol. 24, no. 1, pp. 197-201, 1998.
[140] E. Block, "The chemistry of garlic and onions," Scientific American, vol. 252, no. 3, pp. 114-119, 1985.

[141] M. Ali, M. Thomson, and M. Afzal, "Garlic and onions: their effect on eicosanoid metabolism and its clinical relevance," Prostaglandins Leukotrienes and Essential Fatty Acids, vol. 62, no. 2, pp. 55-73, 2000.

[142] K. P. Pathirage and L. Yunman, "Functional herbal food ingredients used in type 2 diabetes mellitus," Pharmacognosy Reviews, vol. 6, no. 11, pp. 37-45, 2012.

[143] K. T. Augusti and P. T. Mathew, "Lipid lowering effect ollicin (diallyl disulphide oxide) on long term feeding to normal rats," Experientia, vol. 30, no. 5, pp. 468-470, 1974.

[144] P. Rose, M. Whiteman, P. K. Moore, and Z. Z. Yi, "Bioactive S-alk(en)yl cysteine sulfoxide metabolites in the genus Allium: the chemistry of potential therapeutic agents," Natural Product Reports, vol. 22, no. 3, pp. 351-368, 2005.

[145] M. Thomson, H. Drobiova, K. Al-Qattan, R. Peltonen-Shalaby, Z. Al-Amin, and M. Ali, "Garlic increases antioxidant levels in diabetic and hypertensive rats determined by a modified peroxidase method," Evidence-Based Complementary and Alternative Medicine, vol. 2011, Article ID 703049, 8 pages, 2011.

[146] C. Liu, H. Hse, C. Lii, P. Chen, and L. Sheen, "Effects of garlic oil and diallyl trisulfide on glycemic control in diabetic rats," European Journal of Pharmacology, vol. 516, no. 2, pp. 165-173, 2005.

[147] P. T. Mathew and K. T. Augusti, "Studies on the effect of allicin (diallyl disulphide oxide) on alloxan diabetes-part I. Hypoglycaemic action and enhancement of serum insulin effect and glycogen synthesis," Indian Journal of Biochemistry and Biophysics, vol. 10, no. 3, pp. 209-212, 1973.

[148] R. C. Jain and C. R. Vyas, "Garlic in alloxan induced diabetic rabbits," American Journal of Clinical Nutrition, vol. 28, no. 7, pp. 684-685, 1975.

[149] Y. S. Diniz, K. K. H. R. Rocha, G. A. Souza et al., "Effects of $\mathrm{N}$-acetylcysteine on sucrose-rich diet-induced hyperglycaemia, dyslipidemia and oxidative stress in rats," European Journal of Pharmacology, vol. 543, no. 1-3, pp. 151-157, 2006.

[150] B. O. Bever and G. R. Zahnd, "Plants with oral hypoglycemic action," Q Journal Crude Drug Research, vol. 17, pp. 139-149, 1979.

[151] F. M. Al-Awadi and K. A. Gumaa, "Studies on the activity of individual plants of an antidiabetic plant mixture," Acta Diabetologica Latina, vol. 24, no. 1, pp. 37-41, 1987.

[152] K. T. Augusti and C. G. Sheela, "Antiperoxide effect of S-allyl cysteine sulfoxide, an insulin secretagogue, in diabetic rats," Experientia, vol. 52, no. 2, pp. 115-119, 1996.

[153] S. Patumraj, S. Tewit, S. Amatyakul et al., "Comparative effects of garlic and aspirin on diabetic cardiovascular complications," Drug Delivery, vol. 7, no. 2, pp. 91-96, 2000.

[154] H. Matsuura, "Saponins in garlic as modifiers of the risk of cardiovascular disease," Journal of Nutrition, vol. 131, no. 3, pp. 1000S-1005S, 2001.

[155] F. M. El-Demerdash, M. I. Yousef, and N. I. A. El-Naga, "Biochemical study on the hypoglycemic effects of onion and garlic in alloxan-induced diabetic rats," Food and Chemical Toxicology, vol. 43, no. 1, pp. 57-63, 2005.

[156] C. Borek, "Antioxidant health effects of aged garlic extract," Journal of Nutrition, vol. 131, no. 3, pp. 1010S-1015S, 2001.

[157] J. Z. Liu, X. Y. Lin, and J. A. Milner, "Dietary garlic powder increases glutathione content and glutathione $S$-transferase activity in rat liver and mammary tissues," FASEB Journal, vol. 6, abstract A3230, 1992. 
[158] H. R. Madkor, S. W. Mansour, and G. Ramadan, "Modulatory effects of garlic, ginger, turmeric and their mixture on hyperglycaemia, dyslipidaemia and oxidative stress in streptozotocinnicotinamide diabetic rats," British Journal of Nutrition, vol. 105, no. 8, pp. 1210-1217, 2011.

[159] R. Padiya, T. N. Khatua, P. K. Bagul, M. Kuncha, and S. K. Banerjee, "Garlic improves insulin sensitivity and associated metabolic syndromes in fructose fed rats," Nutrition and Metabolism, vol. 8, article 53, 2011.

[160] M. S. Ahmad and N. Ahmed, "Antiglycation properties of aged garlic extract: possible role in prevention of diabetic complications," Journal of Nutrition, vol. 136, no. 3, supplement, pp. 796S-799S, 2006. 


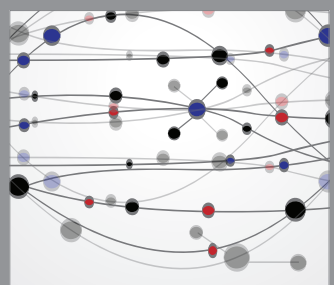

The Scientific World Journal
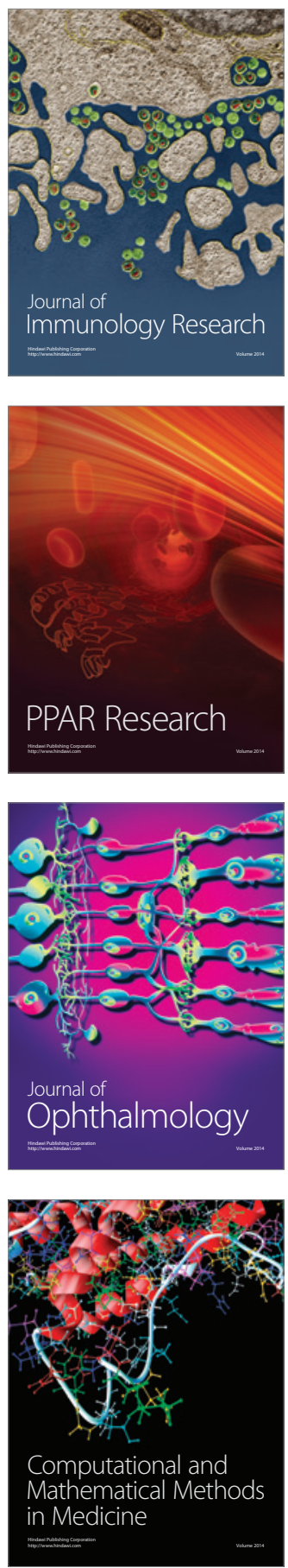

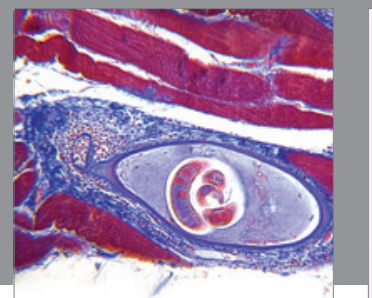

Gastroenterology

Research and Practice
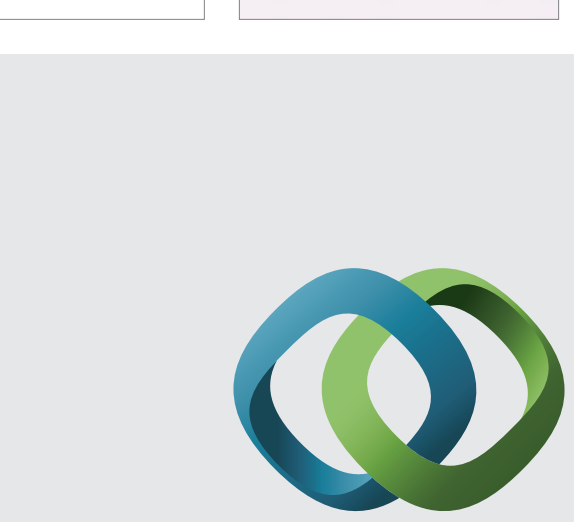

\section{Hindawi}

Submit your manuscripts at

http://www.hindawi.com
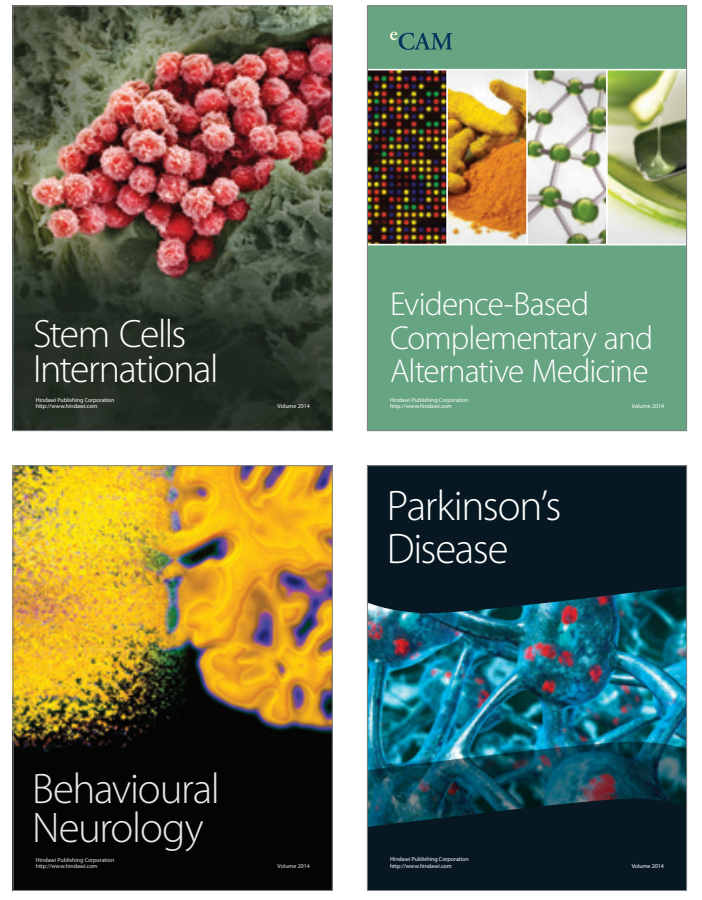
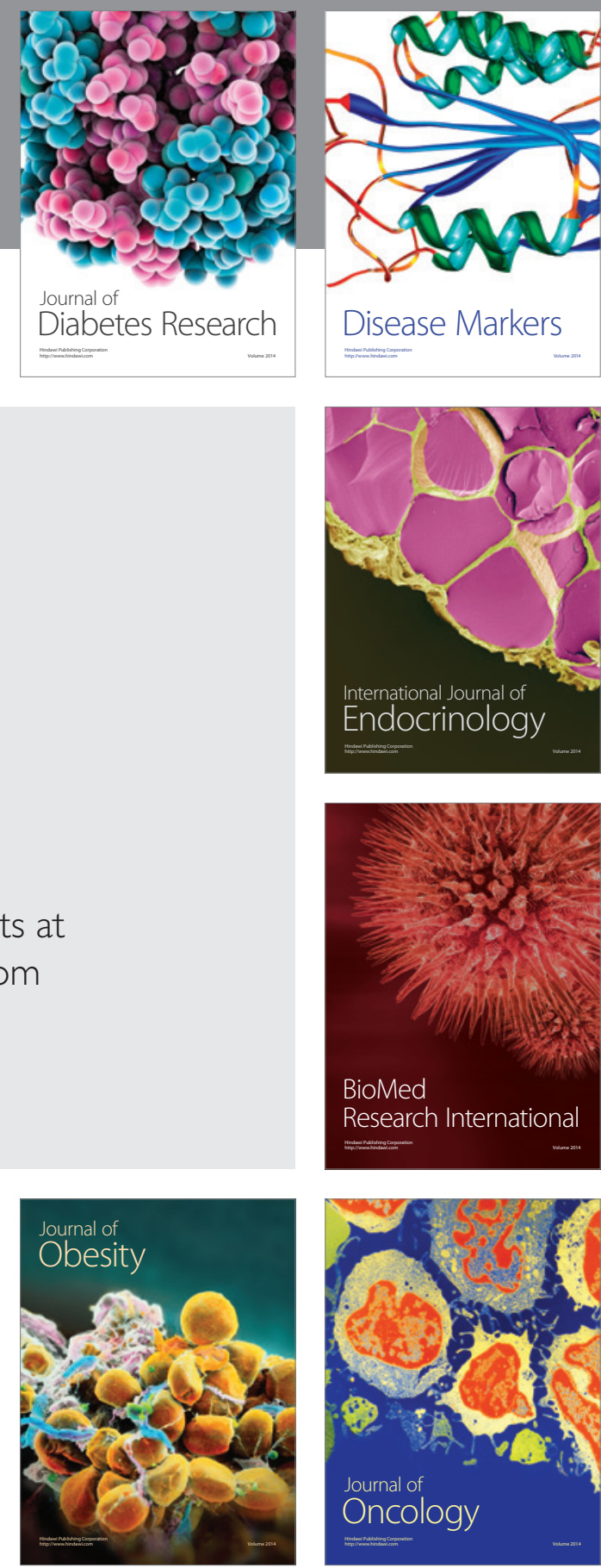

Disease Markers
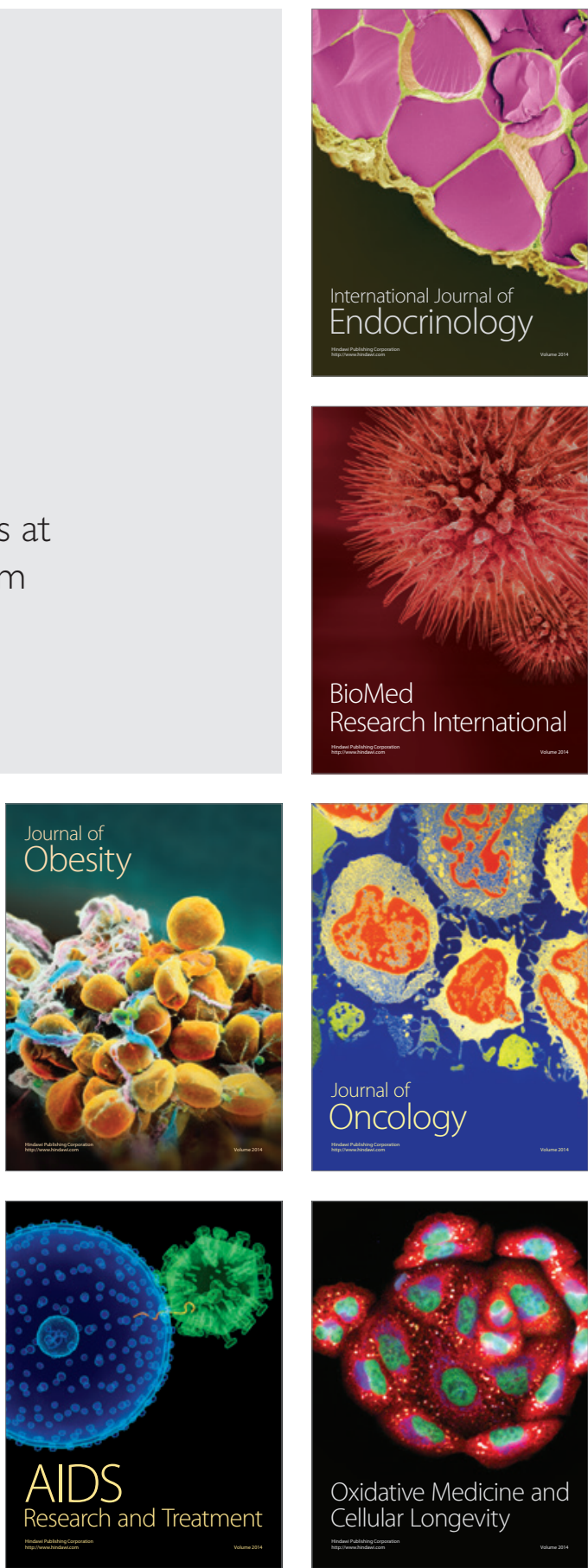